\title{
Faktor yang berhubungan dengan status gizi balita di Kecamatan Kranggan Kabupaten Temanggung
}

\author{
Indah Sovi Savitri a,1 dan Hariza Adnani b,2,* \\ a,bProdi Kesehatan Masyarakat, STIKES Surya Global, Yogyakarta \\ ${ }^{2}$ harizaadnani541@gmail.com \\ *Correspondent Author
}

\section{ARTICLE INFO}

Article history

Received : 23-05-2021

Revised : $31-05-2021$

Accepted : 09-10-2021

Keywords

Infectious Condition; History of Exclusive breastfeeding; History of Breast Milk Complementary Food Nutritional Status.

\section{ABSTRACT}

Previous research found that $4.17 \%$ of children under five who experienced poor nutritional status based on body weight in Klepu Village, Krangan District, Tumangung Regency. The purpose of this study was to determine the factors related to the nutritional status of children under five in Klepu Village, Kranggan District, Temanggung Regency. This observational survey research used a cross sectional study approach. The population consisted of 72 children under five, all of them were research subjects. The data was processed using the chi square test. It was concluded that the factors related to nutritional status were infectious conditions, history of exclusive breastfeeding, history of complementary feeding and income level of parents. Meanwhile, factors that are not related to nutritional status are maternal nutritional knowledge, energy nutrition level and protein consumption level.

This is an open-access article under the CC-BY-SA license.

\section{Pendahuluan}

Gizi adalah suatu proses organisme menggunakan makanan yang dikonsumsi secara normal melalui proses digesti, absorpsi, transportasi, penyimpanan, metabolisme dan pengeluaran zatzat yang tidak digunakan untuk mempertahankan kehidupan, pertumbuhan dan fungsi normal dari organ-organ serta menghasilkan energi (1) .

Masalah gizi adalah gangguan kesehatan seseorang atau masyarakat yang disebabkan karena tidak seimbangnya pemenuhan kebutuhan zat gizi yang diperoleh dari makanan yang dikonsumsi. Masalah gizi dibagi menjadi dua kelompok, yaitu masalah gizi kurang dan masalah gizi lebih (2). Menurut WHO, ASI eksklusif diberikan hingga bayi berusia 6 bulan. Ini berarti bahwa bayi hanya mendapat ASI, tanpa makanan tambahan lain selama itu. Penelitian menunjukkan banyak manfaat yang diperoleh bayi yang mendapatkan ASI eksklusif. Setelah usia 6 bulan, kebutuhan gizi bayi akan menjadi lebih besar. ASI memenuhi sekitar 60-70\% kebutuhan 
tersebut, sehingga nutrisi tambahan perlu diberikan dalam bentuk makanan pendamping ASI (MP-ASI)(3).

Berdasarkan hasil Riset Kesehatan Dasar tahun 2018 menunjukkan bahwa persentase gizi buruk pada balita usia 0-23 bulan di Indonesia adalah 3,8\%, sedangkan persentase gizi kurang adalah 11,4\%. Hasil ini tidak berbeda dengan hasil Pemantauan Status Gizi (PSG) yang diselenggarakan oleh Kementerian Kesehatan tahun 2017, yaitu persentase gizi buruk pada balita usia 0-23 bulan sebesar 3,5\% dan persentase gizi kurang sebesar 11,3\%. Sedangkan untuk provinsi jawa tengah sendiri status gizi buruk balita mencapai 3,50\%, dan persentase status gizi kurang sebesar 11,50\% (4,5). Sedangkan berdasarkan Indikator Kesejahteraan Rakyat Kabupaten Temanggung Tahun 2017, persentase balita gizi baik di Kabupaten Temanggung tahun 2012-2016 cenderung mengalami kenaikan. Namun, untuk status gizi balita dengan status gizi kurang cenderung mengalami penurunan. Pada Tahun 2016, sebanyak 92,91\% balita berstatus gizi baik sedangkan balita yang berstatus gizi buruk/sangat kurang hanya $0,85 \%$ (6).

Puskesmas Kranggan mencakup 7 kelurahan yaitu Kelurahan Kranggan, Pendowo, Sanggrahan, Klepu, Kemloko, Gentan, dan Kramat. Kelurahan Klepu memiliki tingkat gizi buruk yang lebih banyak dibandingkan dengan 6 Kelurahan yang lainya karena terdapat 3 kasus gizi buruk berdasarkan BB/U menurut data sekunder Puskesmas Kranggan di Bulan Oktober 2016.

Berdasarkan hasil wawancara dengan ibu yang memiliki Balita status gizi kurang di Kelurahan Klepu, penyebab anaknya mengalami status gizi kurang karena tidak diberikan ASI eksklusif, dan balitanya sebelum usia 6 bulan sudah diberikan Makanan Pendamping ASI (MPASI). Ibu balita tersebut meyakini, apabila balita mulai diberikan makanan pada usia 6 bulan ke atas, maka anak akan susah untuk menerima makanan yang menyebabkan kurang gizi. Ibu balita tersebut tidak mempertimbangkan penyakit infeksi yang pernah dialami balitanya selama masa pertumbuhannya. Berdasarkan uraian tersebut maka penulis melakukan penelitian yang bertujuan untuk mengetahui faktor-faktor yang berhubungan dengan status gizi balita di Kelurahan Klepu Kecamatan Kranggan Kabupaten Temanggung. Harapannya akan menambah pengetahuan ibu balita terkait pentingnya ASI ekslusif dan MPASI terhadap status gizi balita.

\section{Metode}

Jenis penelitian pada penelitian ini adalah deskriptif kuantitatif, dengan pendekatan cross sectional study. Variabel independen dalam penelitian ini adalah variabel keadaan Infeksi, riwayat ASI Eksklusif, dan riwayat MP-ASI, sedangkan variabel dependennya adalah Status gizi balita. Populasi penelitian dalam penelitian ini adalah ibu yang mempunyai balita usia 6-24 bulan di Kelurahan Klepu Kecamatan Kranggan Kabupaten Temanggung sebanyak 72 
orang (Sumber: Data Posyandu Kelurahan Klepu Bulan Oktober 2016). Sampel penelitian diambil menggunakan nonprobability sampling dengan teknik sampling jenuh, yaitu teknik penentuan sampel bila semua anggota populasi digunakan sebagai sampel (72 orang) (7).

Penelitian ini dilaksanakan pada bulan Maret - April 2017 dimana faktor-faktor yang mempengaruhi status gizi balita dan status gizinya diukur pada rentang waktu satu bulan. Instrumen penelitian. Penelitian dilakukan pada saat kegiatan posyandu dilaksanan dan melalui kunjungan ke rumah. Kunjungan ke rumah ibu balita dilakukan karena ibu balita tidak bisa ditemui pada saat kegiatan posyandu dan atau tidak memanfaatkan fasilitas Posyandu di kelurahan Klepu.

Data primer dalam penelitian ini diperoleh melalui hasil survey dan jawaban responden pada kuesioner yang terdiri dari lembar indikator faktor-faktor yang mempengaruhi status gizi balita. Sedangkan data sekunder dalam penelitian ini diperoleh dari Profil Kesehatan Kabupaten Temanggung, Dinas Kesehatan Temanggung, Puskesmas Kranggan, dan Kader Posyandu Kelurahan Klepu. Teknik analisis data dalam penelitian ini menggunakan analisis statistik chi square karena dalam penelitian ini menggunakan skala data nominal ordinal dan untuk mengetahui hubungan antar variable (8)

\section{Hasil dan Pembahasan}

Berikut ini adalah tabel hubungan antar variabel dari faktor-faktor yang mempengaruhi status gizi balita di Kelurahan Klepu Kecamatan Kranggan Kabupaten Temanggung. Adapun variabel bebasnya adalah: keadaan infeksi, riwayat ASI eksklusif, riwayat MPASI, tingkat pendidikan orangtua, tingkat pendapatan orangtua, tingkat pengetahuan gizi ibu, dan tingkat konsumsi gizi. 
Tabel silang yang memperlihatkan hubungan keadaan infeksi, riwayat ASI eksklusif dan MPASI dengan status gizi Balita dapat dilihat pada Tabel 1:

Tabel 1. Hubungan Antara Keadaan Infeksi, Riwayat ASI Eksklusif dan MP-ASI dengan Status Gizi Balita

\begin{tabular}{|c|c|c|c|c|c|c|c|c|c|}
\hline \multirow{3}{*}{$\begin{array}{c}\text { Hubungan antara } \\
\text { Variabel }\end{array}$} & \multicolumn{6}{|c|}{ Status Gizi Balita } & \multirow{2}{*}{\multicolumn{2}{|c|}{ Jumlah }} & \multirow{3}{*}{$\begin{array}{l}\text { Nilai } p \text { dan } \\
\text { chi square }\end{array}$} \\
\hline & \multicolumn{2}{|c|}{ Baik } & \multicolumn{2}{|c|}{ Kurang } & \multicolumn{2}{|c|}{ Lebih } & & & \\
\hline & $\mathrm{N}$ & $\%$ & $\mathrm{~N}$ & $\%$ & $\mathrm{~N}$ & $\%$ & $\mathrm{~N}$ & $\%$ & \\
\hline Keadaan Infeksi & & & & & & & & & \\
\hline Infeksi & 16 & 22.2 & 2 & 2.8 & 1 & 1.4 & 19 & 26.4 & 0,040 dan \\
\hline Tidak Infeksi & 52 & 72.2 & 0 & 0,0 & 1 & 1,4 & 53 & 73.6 & 6,439 \\
\hline Jumlah & 68 & 94.4 & 2 & 2,8 & 2 & 2,8 & 72 & 100,0 & \\
\hline Riwayat ASI Eksklu & & & & & & & & & \\
\hline $\begin{array}{l}\text { ASI Eksklusif } \\
\text { Tidak }\end{array}$ & 13 & 18.0 & 2 & 2.8 & 1 & 1.4 & 16 & 22.2 & $\begin{array}{c}0,016 \\
\text { dan }\end{array}$ \\
\hline ASI Eksklusif & 55 & 76.4 & 0 & 0,0 & 1 & 1.4 & 56 & 77.8 & 8,272 \\
\hline Jumlah & 68 & 94.4 & 2 & 2.8 & 2 & 2.8 & 72 & 100.0 & \\
\hline Riwayat MP-ASI & 58 & 805 & 0 & 00 & 1 & 14 & 59 & 810 & 0,004 \\
\hline$\geq 6$ bulan & 10 & 13.9 & 2 & 2.8 & 1 & 1.4 & 13 & 18.1 & 10,972 \\
\hline Jumlah & 68 & 94.4 & 2 & 2.8 & 2 & 2.8 & 72 & 100,0 & \\
\hline
\end{tabular}

Pada Tabel 1 diketahui bahwa balita yang tidak terinfeksi pada umumnya status gizi nya baik sebanyak 52 orang (72.2\%), sedangkan balita yang terinfeksi pada umumnya status gizi nya juga baik sebanyak 16 orang (22.2\%). Banyaknya balita tidak terinfeksi dengan status gizi baik lebik banyak daripada balita yang terinfeksi dengan status gizi baik. Hasil Uji chi square, didapatkan nilai sebesar 6,439 dengan $p$ value $=0,040(0,040<0,05)$, sehingga $H_{o}$ dititolak dan $H_{a}$ diterima. Hal ini berarti bahwa ada hubungan yang signifikan antara keadaan infeksi dengan status gizi balita di Kelurahan Klepu Kecamatan Kranggan Kabupaten Temanggung.

Balita dengan ASI eksklusif pada umumnya status gizinya baik sebanyak13 orang (18.0\%), sedangkan balita yang tidak ASI eksklusif pada umumnya status gizi balita baik sebanyak 55 orang (76.4\%). Banyaknya balita tidak ASI eksklusif dengan status gizi baik lebik banyak daripada balita ASI eksklusif dengan status gizi baik. Hasil Uji chi square didapatkan nilai 8,272 dengan $p$ value $=0,016 .(0,016<0,05)$, sehingga $\mathrm{H}_{\mathrm{o}}$ dititolak dan $\mathrm{H}_{\mathrm{a}}$ diterima. Hal ini berarti bahwa ada hubungan yang signifikan antara riwayat ASI eksklusif dengan status gizi balita di Kelurahan Klepu Kecamatan Kranggan Kabupaten Temanggung.

Balita yang MP-ASI diberikan $<6$ bulan pada umumnya status gizi nya baik sebanyak 58 orang ( $80.5 \%$ ), sedangkan balita yang MP-ASI diberikan $\geq 6$ bulan pada umumnya status gizi nya kurang sebanyak 2 orang (2.8\%). Hasil Uji chi square didapatkan nilai sebesar 10,972 dengan $p$ value $=0,004(0,004<0,05)$, sehingga $\mathrm{H}_{\mathrm{o}}$ dititolak dan $\mathrm{H}_{\mathrm{a}}$ diterima. Hal ini berarti bahwa ada 
hubungan yang signifikan antara riwayat MP-ASI dengan status gizi balita di Kelurahan Klepu Kecamatan Kranggan Kabupaten Temanggung.

Tabel silang yang memperlihatkan hubungan tingkat pendidikan, pengetahuan gizi dan tingkat pendapatan orang tua dengan status gizi Balita dapat dilihat pada Tabel 2:

Tabel 2. Hubungan Antara Tingkat Pendidikan Orang Tua, Pengetahuan Gizi Ibu dan Tingkat Pendapatan Orang Tua dengan Status Gizi Balita

\begin{tabular}{|c|c|c|c|c|c|c|c|c|c|}
\hline \multirow{3}{*}{$\begin{array}{c}\text { Hubungan antara } \\
\text { Variabel }\end{array}$} & \multicolumn{6}{|c|}{ Status Gizi Balita } & \multirow{2}{*}{\multicolumn{2}{|c|}{ Jumlah }} & \multirow{3}{*}{$\begin{array}{l}\text { Nilai } p \text { dan } \\
\text { chi square }\end{array}$} \\
\hline & \multicolumn{2}{|c|}{ Baik } & \multicolumn{2}{|c|}{ Kurang } & \multicolumn{2}{|c|}{ Lebih } & & & \\
\hline & $\mathrm{N}$ & $\%$ & $\mathrm{~N}$ & $\%$ & $\mathrm{~N}$ & $\%$ & $\mathrm{~N}$ & $\%$ & \\
\hline \multicolumn{9}{|c|}{ Tingkat Pendidikan Orang Tua } & \multirow{4}{*}{$\begin{array}{c}0,021 \text { dan } \\
11,502\end{array}$} \\
\hline Dasar & 13 & 18.1 & 0 & 0,0 & 0 & 0,0 & 13 & 18.1 & \\
\hline Menengah & 53 & 73.6 & 1 & 1.4 & 2 & 2.8 & 56 & 77.7 & \\
\hline Tinggi & 2 & 2.8 & 1 & 1.4 & 0 & 0,0 & 3 & 4.2 & \\
\hline Jumlah & 68 & 94,4 & 2 & 2,8 & 2 & 2,8 & 72 & 100,0 & \\
\hline \multicolumn{10}{|c|}{ Pengetahuan Orang Tua } \\
\hline Baik & 10 & $13 ., 9$ & 0 & 0,0 & 1 & 1.4 & 11 & 15.3 & \multirow{4}{*}{$\begin{array}{c}0,881 \text { dan } \\
6,153\end{array}$} \\
\hline Cukup & 24 & 33.3 & 2 & 2.8 & 1 & 1.4 & 27 & 37.5 & \\
\hline Kurang & 34 & 47.2 & 0 & 0.0 & 0 & 0,0 & 34 & 47.2 & \\
\hline Jumlah & 68 & 94,4 & 2 & 2,8 & 2 & 2,8 & 72 & 100,0 & \\
\hline \multicolumn{10}{|c|}{ Pendapatan Orang Tua } \\
\hline Rendah & 50 & 69.4 & 0 & 0.0 & 2 & 2.8 & 52 & 72.2 & \multirow{4}{*}{$\begin{array}{l}0.049 \text { dan } \\
6.027\end{array}$} \\
\hline Sedang & 13 & 18.1 & 0 & 0.0 & 0 & 0.0 & 13 & 18.1 & \\
\hline Tinggi & 5 & 6.9 & 0 & 0.0 & 2 & 2.8 & 7 & 9.7 & \\
\hline Jumlah & 68 & 94,4 & 2 & 2,8 & 2 & 2.8 & 72 & 100,0 & \\
\hline
\end{tabular}

Berdasarkan Tabel 2, diketahui bahwa tingkat pendidikan orang tua pada umumnya jenjang menengah dengan status gizi balita baik sebanyak 53 orang (73.6\%), Hasil uji chi square didapatkan nilai $=11,502$ dengan $p$ value $=0,021(0,021<0,05)$. Hal ini berarti bahwa ada hubungan yang signifikan antara tingkat pendidikan orang tua dengan status gizi balita di Kelurahan Klepu Kecamatan Kranggan Kabupaten Temanggung.

Pengetahuan gizi ibu pada umumnya kurang dengan status gizi balita baik sebanyak 34 orang (47.2\%), Hasil uji chi square $=6,153$ dengan $p$ value $=0,188$. Nilai $p$ value lebih besar dari $0,05(0,188>0,05)$. Hal ini berarti bahwa tidak ada hubungan yang signifikan antara pengetahuan gizi ibu dengan status gizi balita di Kelurahan Klepu Kecamatan Kranggan Kabupaten Temanggung. Tingkat pendapatan orang tua pada umumnya rendah dengan status gizi balita baik sebanyak 50 orang (69.4\%), Hasil uji chi square $=6,027$ dengan $p$ value $=0,049$ $(0,049<0,05)$. Hal ini berarti ada hubungan yang signifikan antara pendapatan orang tua dengan status gizi balita di Kelurahan Klepu Kecamatan Kranggan Kabupaten Temanggung. 
Tabel silang yang memperlihatkan hubungan tingkat konsumsi energi dan tingkat konsumsi protein dengan status gizi Balita dapat dilihat pada Tabel 3:

Tabel 3. Hubungan Antara Tingkat Konsumsi Energi dan Tingkat Konsumsi Protein dengan Status Gizi Balita

\begin{tabular}{|c|c|c|c|c|c|c|c|c|c|}
\hline \multirow{3}{*}{$\begin{array}{c}\text { Hubungan antara } \\
\text { Variabel }\end{array}$} & \multicolumn{6}{|c|}{ Status Gizi Balita } & \multirow{2}{*}{\multicolumn{2}{|c|}{ Jumlah }} & \multirow{3}{*}{$\begin{array}{l}\text { Nilai } p \text { dan } \\
\text { chi square }\end{array}$} \\
\hline & \multicolumn{2}{|c|}{ Baik } & \multicolumn{2}{|c|}{ Kurang } & \multicolumn{2}{|c|}{ Lebih } & & & \\
\hline & $\mathrm{N}$ & $\%$ & $\mathrm{~N}$ & $\%$ & $\mathrm{~N}$ & $\%$ & $\mathrm{~N}$ & $\%$ & \\
\hline \multicolumn{9}{|c|}{ Tingkat Konsumsi Energi } & \multirow{6}{*}{$\begin{array}{c}0,482 \text { dan } \\
5,494\end{array}$} \\
\hline Baik & 38 & 52.8 & 1 & 1.4 & 1 & 1.4 & 40 & 55.6 & \\
\hline Sedang & 9 & 12.5 & 0 & 0,0 & 1 & 1.4 & 10 & 13.9 & \\
\hline Kurang & 8 & 11.1 & 1 & 1.4 & 0 & 0,0 & 9 & 12.5 & \\
\hline Defisit & 13 & 18.0 & 0 & 0,0 & 0 & 0,0 & 13 & 18.0 & \\
\hline Jumlah & 68 & 94,4 & 2 & 2,8 & 2 & 2,8 & 72 & 100,0 & \\
\hline \multicolumn{10}{|c|}{ Tingkat Konsumsi Protein } \\
\hline Baik & 55 & 76.3 & 2 & 2.8 & 2 & 2.8 & 59 & 81.9 & \multirow{4}{*}{$\begin{array}{c}0,988 \text { dan } \\
0,933\end{array}$} \\
\hline Sedang & 4 & 5.6 & 0 & 0,0 & 0 & 0,0 & 4 & 5.6 & \\
\hline Kurang & 4 & 5.6 & 0 & 0,0 & 0 & 0,0 & 4 & 5.6 & \\
\hline Defisit & 5 & 6.9 & 0 & 0,0 & 0 & 0,0 & 5 & 6.9 & \\
\hline Jumlah & 68 & 94,4 & 2 & 2,8 & 2 & 2,8 & 72 & 100,0 & \\
\hline
\end{tabular}

Berdasarkan Tabel 3, dapat diketahui bahwa tingkat konsumsi energi pada umumnya baik dengan status gizi balita baik sebanyak 38 (52.8 \%). Hasil uji chi square didapatkan nilai chi square $=5,494$ dengan $p$ value $=0,482(0,482>0,05)$, sehingga $\mathrm{H}_{\mathrm{o}}$ diterima dan $\mathrm{H}_{\mathrm{a}}$ ditolak. Hal ini berarti bahwa tidak ada hubungan yang signifikan antara tingkat konsumsi energi dengan status gizi balita di Kelurahan Klepu Kecamatan Kranggan Kabupaten Temanggung. Tingkat konsumsi protein pada umumnya baik dengan status gizi balita baik sebanyak 55 (76.3\%). Hasil uji chi square didapatkan nilai $=0,988$ dengan $p$ value $=0,988(0,988>0,05)$, sehingga $\mathrm{H}_{\mathrm{o}}$ diterima dan $\mathrm{H}_{\mathrm{a}}$ ditolak. Hal ini berarti bahwa tidak ada hubungan yang signifikan antara tingkat konsumsi protein dengan status gizi balita di Kelurahan Klepu Kecamatan Kranggan Kabupaten Temanggung.

Berdasarkan hasil analisis bivariat menunjukkan ada hubungan antara keadaan infeksi dengan status gizi balita di Kelurahan Klepu Kecamatan Kranggan Kabupaten Temanggung tahun 2017. Penyakit infeksi yang banyak diderita oleh balita di Kelurahan Klepu adalah diare dan riwayat penyakit ISPA. Hal ini menyebabkan status gizi balita kurang, karena menurut hasil penelitian lain menyebutkan bahwa penyebab gizi kurang tidak hanya disebabkan makanan yang kurang tetapi juga karena penyakit. Anak yang mendapatkan makanan yang baik tetapi karena sering sakit diare atau demam dapat menderita kurang gizi. Demikian pada anak yang makanannya tidak cukup baik maka daya tahan tubuh akan melemah dan mudah terserang penyakit $(1,9)$. 
Keadaan status malnutrisi akan membawa dampak yang luas diantaranya mudahnya anak mengalami infeksi serta gangguan tumbuh kembang dan gangguan fungsi organ tubuhnya, dan berpengaruh besar terhadap kenaikan berat badan anak. Hasil penelitian ini sesuai dengan hasil penelitian yang antara lain menyatakan penyakit infeksi memiliki hubungan yang bermakna dengan status gizi pada anak balita serta memiliki hubungan timbal balik antara penyakit infeksi dan kemudahan terserang penyakit infeksi (9-13).

Hasil analisis bivariat menunjukkan ada hubungan antara riwayat ASI eksklusif dengan status gizi balita di Kelurahan Klepu Kecamatan Kranggan Kabupaten Temanggung Tahun 2017. ASI sebagai makanan tunggal untuk memenuhi kebutuhan pertumbuhan sampai usia 6 bulan. Makanan lain yang diberikan terlalu dini justru dapat meningkatkan penyakit infeksi pada bayi yang secara langsung berpengaruh terhadap status gizi (1).

Hasil penelitian ini sejalan dengan beberapa penelitian yang telah dilakukan, dimana riwayat ASI ekslusif memiliki hubungan dengan status gizi pada balita $(14,15)$. Asi ekslusif diberikan setelah bayi lahir hingga umur 6 bulan tanpa diikuti dengan makanan atau cairan lain tanpa obat dan vitamin. Selanjutnya pemberian ASI eklusif ini diberikan hingga bayi berumur 24 bulan, berdasarkan penelitian Afriani et.al (2018) status gizi dipengaruhi oleh beberapa faktor, tidak hanya melalui riwayat ASI eklsusif. Namun, bayi yang tidak diberikan ASI ekskusif memiliki risiko sakit yang lebih tinggi dibandingkan dengan anak yang diberikan ASI ekslusif akan memiliki imun yang lebih kuat dan risiko sakit lebih kecil. Selain itu, ibu yang tidak memberikan ASI ekslusif akan berdapat pada anak yaitu gizi yang kurang dan buruk dan memiliki status gizi lebih buruk dibandingkan dengan ibu yang memberikan ASI ekslusif (16).

ASI mengandung nutrisi lengkap yang dibutuhkan oleh sistem imun bayi. Keunggulan lainnya adalah ASI cocok untuk sistem pencernaan bayi, sehingga nutrisinya cepat diserap. Hal ini berbeda dengan susu formula atau makanan lain yang diberikan kepada bayi sejak dini. Susu formula sulit diserap usus bayi, sehingga dapat menyebabkan sembelit pada bayi. Proses pembuatan susu formula yang tidak steril dapat menyebabkan bayi mengalami diare. Hal ini dapat menyebabkan kekurangan gizi pada anak-anak (17).

Hasil analisis bivariat menunjukkan ada hubungan antara riwayat MP-ASI dengan status gizi balita di Kelurahan Klepu Kecamatan Kranggan Kabupaten Temanggung Tahun 2017. Hasil penelitian ini sesuai dengan hasil penelitian dari Yogi (2014) yang antara lain menyatakan riwayat pemberian Makanan Pendamping Air Susu Ibu (MP-ASI) memiliki pengaruh terhadap status gizi pada bayi usia 6-12 bulan di wilayah Kerja Puskesmas Badegan Kabupaten Ponorogo (18). Makanan Pendamping ASI (MP-ASI) dapat meningkatkan konsumsi zat gizi pada anak secara optimum pada balita usia diatas 12 bulan, dengan pemberian MP-ASI anak akan 
mendapatkan asupan energy dan protein disamping pemberian ASI ekslusif sehingga akan meningkatkan system kekebalan tubuh anak (11).

Hasil analisis bivariat menunjukkan ada hubungan antara tingkat pendidikan orang tua dengan status gizi balita di Kelurahan Klepu Kecamatan Kranggan Kabupaten Temanggung Tahun 2017. Hasil penelitian ini sesuai dengan penelitian yang dilakukan di Posyandu Melati Kota Bambu Selatan dimana pendidikan ibu memilik hubungan terhadap status gizi kurang pada balita. Pendidikan akan sangat berpengatuh kepada pengetahuan ibu dalam menyerapinformais yang diberikan baik oleh dokter maupun kader posyandu. Ibu dengan pendidikan menengah lebih aktif untuk menanyakan terkait gizi balita dibandingkan dnegan ibu dengan gizi kurang, sehingga perlu diadakan penyuluhan dan konseling dasar untuk membantu ibu-ibu memiliki pengetahuan yang baik dibantu oleh kader dan petugas puskesmas (14). Penelitian lain juga menyatakan pendidikan ibu berhubungan dengan status gizi anak, hal ini akan mempengaruhi pola asuh dan meningkatkan status gizi anak kepada anak. Kurangnya pendidikan ibu akan berpengaruh pada pola asuh yang buruk dan pemenuhan gizi anak yang tidak tercukupi karena sangat berpengaruh terhadap prilaku dalam pemilihan bahan pangan dan penyediaan makanan keluarga $(9,19)$.

Hasil analisis bivariat menunjukkan tidak ada hubungan antara pengetahuan gizi ibu dengan status gizi balita di Kelurahan Klepu Kecamatan Kranggan Kabupaten Temanggung Tahun 2017. Ibu yang mempunyai pengetahuan gizi dan kesadaran gizi tinggi akan melatih kebiasaan makan yang sehat sedini mungkin kepada anak-anaknya. Keadaan ini menunjukkan ketidaktahuan akan faedah makanan bagi kesehatan tubuh, merupakan sebab buruknya mutu gizi makanan keluarga. Dengan pengetahuan gizi yang dimiliki ibu, maka ibu akan memiliki kesadaran mengenai makanan yang bergizi tinggi akan melatih anak untuk dapat menerapkan kebiasaan makan makanan yang sehat (13).

Pengetahuan ibu didukung dengan pendidikan yang dimiliki oleh ibu, pengetahuan ibu yang baik akan menentukan kadar gizi dan mengetahui asupan gizi yang penting untuk balita sehingga dapat diterapkan pada kehidupan sehari-hari dengan memperhatian setiap makanan bergizi yang masuk ke dalam tubuh balita dengan benar. Pengetahuan menjadi faktor yang berpengaruh dalam konsumsi pangan serta status gizi balita. Semakin baik status gizi balita maka pengetahuan gizi yang dimiliki ibu cenderung baik. Dengan pengetahuan gizi yang cukup, segala sesuatu yang berhubungan dengan makanan, mulai dari persiapan dan pengolahan hingga penyediaan makanan untuk anak, dapat dilakukan lebih baik daripada ibu dengan pengetahuan gizi yang kurang. Ibu akan berusaha memenuhi kebutuhan gizi setiap anggota keluarga sesuai dengan pengetahuannya sendiri. Pengetahuan tentang gizi ini dapat diperoleh dan ditingkatkan 
dengan selalu mengikuti anjuran gizi dan kesehatan yang diberikan oleh petugas kesehatan di puskesmas atau posyandu-posyandu. $(9,13,16,20-22)$.

Hasil penelitian ini menunjukkan bahwa tidak ada hubungan antara pengetahuan gizi ibu dengan status gizi balita di Kelurahan Klepu Kecamatan Kranggan Kabupaten Temanggung. Hasil penelitian ini bertentangan dengan hasil penelitian dari Weya et al (2018) yang menyatakan bahwa terdapat hubungan antara pengetahuan ibu dan status gizi balita di Puncak Jaya Kabupaten Papua dengan p-value 0,000; RP = 4,702; CI95\% (3,005 - 7,359) (23). Penelitian lain adalah dari Labada yang menyatakan pengetahuan ibu berhubungan dengan status gizi anak. Pengetahuan adalah pedoman dalam membentuk tindakan seseorang (perilaku terbuka). Perilaku berdasarkan pengetahuan akan bertahan lama lebih lama dari perilaku yang tidak berdasarkan pengetahuan $(19,23,24)$

Hasil analisis bivariat menunjukkan ada hubungan antara tingkat pendapatan orang tua dengan status gizi balita di Kelurahan Klepu Kecamatan Kranggan Kabupaten Temanggung Tahun 2017. Beberapa penelitian menunjukkan bahwa terdapat hubungan antara pendapatan yang dimiliki oleh orang tua berhubungan dengan status gizi yang dimiliki oleh balita. faktor ekonomi merupakan akar masalah terjadinya gizi kurang. Kemampuan keluarga untuk mencukupi kebutuhan makanan dipengaruhi oleh tingkat pendapatan keluarga itu sendiri. Pendapatan orang tua yang tinggi dapat meningkatkan status gizi anak balita. Semakin baik pendapatan maka gizi balita akan semakin baik pula (25-27).

Status ekonomi dan pendapatan dalam sebuah keluarga sangat penting terutama pada keluarga yang memiliki balita. Hal ini sangat berpengaruh pada status gizi balita tersebut. Status ekonomi keluarga yang baik akan sebanding dengan status gizi yang dimiliki oleh anak. Keluarga yang memiliki pendapatan yang besar dapat mencukupi dan menjamin kebutuhan gizi yang dibutuhkan oleh anggota keluarga dan gizi balita akan ikut terpenuhi baik dari makanan yang dikonsumsi akan semakin beraneka ragam dan nilai asupan energy balita semakin baik. Selain mempengaruhi pemenuhan gizi anggota keluarga dan balita, pendapatan juga akan mempengaruhi daya beli ibu terhadap bahan pangan yang akan dikonsumsi. Apabila pendapatan keluarga kurang maka dapat dibantu dengan pengetahuan ibu yang baik untuk tetap memenuhi kebutuhan gizi keluarga dengan membeli bahan makanan yang memiliki harga terjangkau sehingga kadar gizi terpenuhi dan makanan yang dikonsumi tetap beraneka ragam $(12,14,16,17,21,22)$

Hasil analisis bivariat menunjukkan tidak ada hubungan antara tingkat konsumsi energi dengan status gizi balita di Kelurahan Klepu Kecamatan Kranggan Kabupaten Temanggung Tahun 2017. Tingkat konsumsi ditentukan oleh kuantitas secara kualitas hidangan yang tersedia 
didalam keluarga. Kualitas hidangan menunjukkann adanya semua zat gizi yang diperlukan tubuh dalam susunan hidangan dan perbandingan yang satu terhadap yang lain. Kuantitas menunjukkan kuantum masing-masing zat gizi terhadap kebutuhan tubuh. Bila susunan hidangan memenuhi kebutuhan tubuh, baik dari segi kualitas maupun kuantitasnya, maka tubuh akan dapat kodisi kesehatan gizi yang baik. Konsumsi yang menghasilkan kesehatan gizi yang sebaik-baiknya disebut konsumsi yang adekuat. Hal ini diduga karena status gizi tidak hanya dipengaruhi oleh angka kecukupan energi saja (2).

Menurut Supariasa, status gizi dapat juga dipengaruhi oleh faktor lainnya yaitu seperti faktor genetik, faktor lingkungan, faktor psikis, jenis kelamin, faktor kesehatan, obat, faktor perkembangan dan aktifitas fisik. Pada keluarga dengan anggota cukup, distribusi makanan yang dikonsumsi semakin buruk. Tingkat konsumsi pangan rumah tangga dengan 6 anggota atau lebih terus menurun. Dalam keluarga yang terdiri dari 3-5 orang, rata-rata asupan energi dan protein masih mendekati nilai yang dianjurkan. Dengan kata lain tingkat konsumsi anggota keluarga jumlah dan jenis makanan yang dibeli, memasak, distribusi dalam rumah tangga, dan kebiasaan makan pribadi. Konsumsi juga tergantung pada pendapatan, agama, adat istiadat dan pendidikan keluarga yang bersangkutan $(28,29)$.

\section{Kesimpulan}

Berdasarkan hasil penelitian tentang faktor-faktor yang berhubungan dengan status gizi balita di Kelurahan Klepu Kecamatan Kranggan Kabupaten Temanggung dapat disimpulkan bahwa ada hubungan antara keadaan infeksi riwayat ASI eksklusif, riwayat MP-ASI, tingkat pendidikan orang tua dan tingkat pendapatan orang tua dengan status gizi balita di Kelurahan Klepu Kecamatan Kranggan Kabupaten Temanggung. Kemudian, Tidak ada hubungan antara pengetahuan gizi ibu, tingkat konsumsi gizi energi dan tingkat konsumsi protein dengan status gizi balita di Kelurahan Klepu Kecamatan Kranggan Kabupaten Temanggung.

\section{Ucapan Terimakasih}

Penulis mengucapkan terima kasih kepada beberapa pihak yang telah membantu selama proses penelitian terutama kepada Kelurahan Klepu Kecamatan kranggan Kabupaten Temanggung yang telah memberi ijin peneliti melaksanakan penelelitian.

\section{Konflik Kepentingan}


Penulis menyatakan jika artikel ini tidak ada konflik kepentingan.

\section{References}

1. Waryana. Gizi Reproduksi. Yogyakarta: Pustaka Rihana; 2010.

2. Andriani, $M$ dan Wirjatmadi B. Gizi dan Kesehatan Balita. Jakarta: Kencana Prenadamedia Group; 2014.

3. Istiany A, Rusilanti. Gizi Terapan. Bandung: Remaja Rosdakarya; 2013.

4. Kemenkes RI. Indonesian Health Profile 2019 [Internet]. Indonesian Ministry of Health Information Center. Jakarta: Kementerian Kesehatan RI; 2020. 98 p. Available from: www.journal.uta45jakarta.ac.id

5. Riskesdas KRI. Hasil Utama Riset Kesehatan Dasar (RISKESDAS) [Internet]. Balai Penelitian dan Pengembangan Kesehatan. Jakarta; 2018.

6. Dinas Komunikasi dan Informatika Kabupaten Temanggung. Indikator Kesejahteraan Rakyat (INKESRA) Kabupaten Temanggung tahun 2017. Dinas Komunikasi dan Informatika Kabupaten Temanggung. Jawa Tengah; 2017. 1-85 p.

7. Sugiyono. Metode Penelitian Kuantitatif Kualitatif dan R\&D. Bandung: Alfabeta; 2015.

8. Soekitjo Notoatmodjo. Metodologi Penelitian Kesehatan. Jakarta: Rineka Cipta; 2012.

9. Suzanna S, Budiastutik I, Marlenywati M. Analisis faktor yang berhubungan dengan status gizi anak usia 6-59 bulan. J Vokasi Kesehat. 2017;3(1):35.

10. Septianasari FT. Faktor-faktor yang berhubungan dengan status gizi balita. J Media Kesehat. 2018;8(2):190-7.

11. Triana W. FAktor yang berhubungan dengan status gizi balita di Wilayah Kerja Puskesmas Penyengat Olak Kabupaten Muaro Jambi Tahun 2017. J Bahana Kesehat Masy. 2017;1(2):150-9.

12. Oktavia S, Widajanti L, Aruben R. Faktor-faktor yang berhubungan dengan status gizi buruk pada balita di Kota Semarang Tahun 2017 (studi di rumah pemulihan gizi Banyumanik Kota Semarang). J Kesehat Masy. 2017;5(3):186-92.

13. Afriani A, Harahap JR, Helina S. Faktor-faktor yang berhubungan dengan status gizi balita di Kelurahan Labuh Baru Barat Kota Pekanbaru Tahun 2018. J Ibu dan Anak. 2018;6(2):74-80.

14. Vionalita G, Sari RN. Faktor-faktor berhubungan dengan status gizi kurang pada anak 
balita di Posyandu Melati Wilayah Kerja Puskesmas Kota Bambu Selatan. Nutr Diaita. 2019;11(1):33-41.

15. Dezi I, Nova M, Nadilla. Faktor-faktor yang berhubungan dengan status gizi anak balita di Wilayah Kerja Puskesmas Dadok Tunggul Hitam Tahun 2019. J Kesehat Saintika Meditory. 2019;3(1):52-61.

16. Hidayah N, Kasman K, Mayasari M. Faktor-faktor yang berhubungan dengan status gizi di Wilayah Kerja UPT.Puskesmas Kertak Hanyar Kabupaten Banjar. An-Nadaa J Kesehat Masy. 2018;5(1):17-24.

17. Estri BA. Faktor -faktor yang berhubungan dengan status gizi pada balita di Posyandu Jambu Desa Bogoran Yogyakarta. Intan Husada J Ilmu Keperawatan. 2019;7(1):41-57.

18. Yogi ED. Pengaruh pola pemberian asi dan pola makanan pendamping asi terhadap status gizi bayi usia 6-12 bulan. J Delima Harapan. 2014;2(1):14-8.

19. Labada A, Ismanto AY, Kundre R. Hubungan karakteristik ibu dengan status gizi balita yang berkunjung di Puskesmas Bahu Manado. eJournal Keperawatan (eKp). 2017;4(1).

20. Nurdiana, Andriani D, Syahradesi Y. Faktor-faktor yang berhubungan dengan status gizi balita di Puskesmas Ngkeran Kecamatan Lawe Alas Kabupaten Aceh Tenggara. J Ners Nurul Hasanah. 2021;8(3):27-38.

21. Wardani ND. Faktor-faktor yang berhubungan dengan status gizi pada balita di Puskesmas Unaha Tahun 2017. 2017. p. 1-76.

22. Prawitasari S, Hasibuan B, Sonia B. Faktor-faktor yang berhubungan dengan status gizi pada balita di Kecamatan Dewantara Kabupaten Aceh Utara. J Healthc Technol Med. 2018;4(2):403-10.

23. Weya A, Rantetampang AL, Tingginehe R, Mallongi A. Factors affecting nutrient status of children under five years at Puncak Jaya District Sub Province Papuan. Int J Sci Healthc Res. 2018;3(4):70-80.

24. Maryam S. Promosi Kesehatan. Jakarta: EGC; 2014.

25. Helmi R. Faktor-faktor yang berhubungan dengan status gizi pada balita di Wilayah Kerja Puskesmas Margototo Kecamatan Metro Kibang Kabupaten Lampung Timur. J Kesehat [Internet]. 2013;IV(1):233-42. Available from: https://ejurnal.poltekkestjk.ac.id/index.php/JK/article/viewFile/6/5

26. Putri RF, Sulastri D, Lestari Y. Faktor-faktor yang berhubungan dengan status gizi anak 
balita di Wilayah Kerja Puskesmas Nanggalo Padang. J Kesehat Andalas. 2015;4(1):254-61.

27. Gusrianti G, Azkha N, Bachtiar H. Analisis faktor yang berhubungan dengan status gizi balita di Kelurahan Limau Manis Selatan Wilayah Kerja Puskesmas Pauh Kota Padang. J Kesehat Andalas. 2020;8(4):109-14.

28. Supariasa B dan IF. Penilaian Status Gizi. Jakarta: EGC; 2014.

29. Handayani R. Faktor-faktor yang berhubungan dengan status gizi pada anak balita. J Endur. 2017;2(2):217-24. 